\title{
Pembelajaran Daring Anak Usia Dini dengan Orang Tua Ter-PHK
}

\author{
Putu Aditya Antara ${ }^{\circledR}$, Ni Wayan Meli Udayani ${ }^{1}$, Gusti Ayu Tara Ari Suryani ${ }^{1}$, Kadek \\ Maharani Kresna Astiti PS1, Ni Wayan Lestari ${ }^{1}$ \\ Pendidikan Guru Pendidikan Anak Usia Dini, Universitas Pendidikan Ganesha, Indonesia(1) \\ DOI: $\underline{10.31004 / o b s e s i . v 6 i 4.1623}$
}

\begin{abstract}
Abstrak
Pandemi telah membuat banyak karyawan diputus hubungan kerja (PHK), termasuk para orang tua anak usia dini yang sedang bersekolah. Menghadapi kondisi ini orang tua ter-PHK memiliki berbagai permasalahan dan solusi menghadapi kondisi tersebut. Hal ini menjadi urgensi kajian dengan tujuan mengetahui bentuk-bentuk kegiatan pembelajaran daring pada orang tua ter-PHK, permasalahan dan solusi pembelajaran daring anak usia dini. Metode kualitatif dipilih dengan pendekatan studi kasus melalui wawancara, observasi dan dokumentasi. Lokasi penelitian di Kabupaten Gianyar, Bali. Hasil menunjukkan bahwa bentuk-bentuk pembelajaran daring yaitu orang tua ter-PHK bisa melakukan pendampingan berkualitas karena mempunyai waktu untuk mendampingi anak belajar daring lebih banyak. Pemberian motivasi yang membangun semangat anak tetap belajar daring. Pengawasan yang berkelanjutan bisa dilakukan pada berbagai kegiatan belajar anak. Permasalahan berupa dana pendidikan, kebosanan dan kemalasan belajar anak. Solusi yang ditemukan yaitu bimbingan terarah pada aktifitas pembelajaran daring anak, apresiasi atas berbagai pencapaian pembelajaran, berjualan serta berladang merupakan pilihan prospetif.
\end{abstract}

Kata Kunci: pembelajaran daring; orang tua ter-phk; anak usia dini

\begin{abstract}
The pandemic has caused many employees to be laid off, including parents of young children who are currently in school. Facing this condition, parents who have been laid off have various problems and solutions to these conditions. This becomes the urgency of the study with the aim of knowing the forms of online learning activities for parents who have been laid off, problems and solutions for online learning for early childhood. The qualitative method was chosen with a case study approach through interviews, observation and documentation. The research location is in Gianyar Regency, Bali. The results show that online learning forms, namely parents who have been laid off can provide quality assistance because they have more time to assist children in online learning. Providing motivation that builds children's enthusiasm to continue learning online. Continuous supervision can be carried out on various children's learning activities. Problems in the form of education funds, boredom and laziness in children's learning. The solutions found are directed guidance on children's online learning activities, appreciation for various learning achievements, selling and farming are prospective choices.
\end{abstract}

Keywords: online learning; laid off parents; early childhood

Copyright (c) 2022 Putu Aditya Antara, et al.

$\triangle$ Corresponding author :

Email Address : putuaditya.antara@undiksha.ac.id (Singaraja,Bali,Indonesia)

Received 9 July 2021, Accepted 8 September 2021, Published 5 February 2022 


\section{PENDAHULUAN}

Pada akhir tahun 2019, dunia dikejutkan dengan ditemukannya Corona Virus Disease 19 (Covid-19). Virus ini awalnya ditemukan di Wuhan-China dan dengan waktu sangat cepat menyebar ke berbagai negara di dunia termasuk Indonesia. Sampai akhirnya WHO pada tanggal 11 Maret 2020 menyatakan bahwa Covid-19 sebagai pandemi. Seperti yang kita ketahui dengan adanya pandemi sangat berpengaruh pada berbagai aspek kehidupan di dunia, tidak bisa dipungkiri bahwa bidang pendidikan terkena dampak yang sangat signifikan (Supriatna, 2020). Dengan adanya pendemi ini sekolah mulai taman kanak-kanak sampai dengan perguruan tinggi melaksanakan pembelajaran daring sehingga tidak ada lagi pelaksanaan pembelajaran tatap muka konvensional. Kementerian Pendidikan dan Kebudayaan mengeluarkan surat edaran pandemi yang diseluncurkan Menteri Pendidikan dan Kebudayaan menyampaikan peraturan dimana pembelajaran yang dilaksankan harus secara daring atau pembelajaran jarak jauh, hal ini menunjukkan bahwa proses pembelajaran harus tetap dilakukan meskipun tidak tatap muka namun tetap berorientasi membangun pembelajaran bermakna (Kemendikbud, 2020).

Covid-19 yang berdampak pula pada kondisi psikologis seseorang yang bisa memicu stress dan cemas. Selain itu, dampak lain yang ditimbulkan dari adanya virus corona ini yaitu banyak orang tua yang mengalami kehilangan pekerjaan atau terputus hubungan kerja (terPHK). Dengan adanya PHK pada salah satu anggota keluarga apalagi itu merupakan tulang punggung keluarga akan sangat berdampak terhadap kondisi keuangan dan ekonomi yang keluarga yang ter-PHK dan juga anggota keluarganya. Kondisi Pemutusan Hubungan Kerja (PHK) diakibatkan oleh banyaknya perusahaan atau pabrik-pabrik yang harus melakukan hal tersebut terhadap sebagian karyawannya karena perusahaan tidak sanggup lagi menanggung pengeluaran dengan jumlah karyawan yang banyak (Nasution et al., 2020). (Ngadi et al., 2020) menyatakan bahwa wilayah dengan jumlah kasus PHK paling tinggi terjadi di BaliNusa Tenggara (39,9 persen) dan Banten (24,8 persen). Selain mengalami PHK, sebagian buruh/pekerja di Bali mengalami penurunan pendapatan di atas 50 persen (16,7 persen). Perekonomian Bali digerakkan oleh 3 sektor utama, yaitu sektor pariwisata, industri pengolahan, dan pertanian (BPS Provinsi Bali, 2019). Beberapa usaha yang digerakkan oleh sektor pariwisata di Bali diantaranya adalah kegiatan biro perjalanan, transportasi, perhotelan, restoran dan rumah makan, kesenian dan budaya daerah, industri kerajinan rakyat, serta tempat hiburan dan rekreasi. Pandemi COVID-19 menyebabkan kinerja sektor ini lumpuh sehingga mem- PHK cukup banyak pekerja. Bahkan kasus PHK tanpa pesangon di provinsi ini merupakan yang tertinggi di Indonesia (35,3 persen).

Kondisi seperti di atas pada jejang pendidikan anak usia dini tetap dilaksanakan proses pembelajaran, bahkan dengan adanya pembelajaran daring perhatian yang diberikan lebih dari pembelajaran pada saat kondisi normal. Anak sejak dini harus dipersipakan dalam pemberian stimulasi, stimulasi berupa pengetahuan, fisik, serta yang tidak kalah pentingnya yaitu pembinaan mental sosial. Hal tersebut perlu diberikan sejak dini karena anak sebagai generasi untuk meneruskan bangsa yang tidak ternilai harganya (Antara, 2017). Anak usia dini adalah kelompok usia dimana berada dalam tahap perkembangan yang unik mengapa demikian karena tahap perkembangan anak terjadi berbarengan dengan masa peka yang dikenal juga dengan masa keemasan. (P.A Antara, 2015) menyatakan bahwa sebagai orang tua selalu harus menerima tantangan yang diperlihatkan anak, karena setiap anak mempunyai keanekaragamaan dalam intelektual, fisik, sikap dan yang lainya. Dengan cara anak banyak memiliki pertanyaan-pertanyaan untuk mejawab rasa ingin tahu anak. Pada saat anak berada pada masa usia dini maka membutuhkan adanya bantuan, layanan dan support dari orang yang berada disekitar anak, mulai dari kebutuhan rohani, kebutuhan semua tahap perkembangan anak. (P.A Antara, 2019) menyatakan bahwa bentuk-bentuk layanan yang diberikan pada anak usia dini yaitu pendidikan anak usia dini. Yang termasuk dalam pendidikan anak usia dini yaitu TPA (Taman Penitipan Anak), KB ( Kelompok Bermain) dan TK (Taman Kanak-Kanak). 
Anak usia dini yaitu anak dengan rentang usia baru lahir sampai enam tahun, yang memiliki karakteristik, diantaranya 1. Anak yang memiliki sifat unik, 2. Anak menunjukkan eskpresi dengan spontan, 3. Anak memiliki sifat penuh energi, 4. Anak masih berada pada tahap egosentris (Khairi, 2018). (P.A Antara, 2019) menyebutkan bahwa terdapat kemampuan dasar yang menjadi pembiasaan, aspek tersebut antara lain, (1) Perkembangan moral agama (2) perkembangan Sosial-emosional (3) perkembangan Fisik-motorik(4) perkembangan Kognitif (5) Daya cipta yaitu seni dan (6) perkembangan bahasa. (Chapnick, 2008) menyatakan bahwa Seorang manusia sesungguhnya sudah mulai belajar sejak mereka dilahirkan. Anak sejak lahir sampai 6 tahun merupakan usia anak yang sedang aktif-aktifnya, usia anak yang senang mencari tahu, dan di usia ini syaraf otak anak sedang sangat baik berkembang serta mereka semua kejadian, pengalaman, dan hal lainnya yang panca indranya tangkap. Pada anak berada pada rentang usia 0 sampai dengan 6 tahun anak mengalami masa keemasan yang disebut dengan (The Golden Age), pada tahap ini anak mulai memiliki rasa peka terhadap berbagai rangsangan yang diterima anak. Taman kanak-kanak ialah jalur pendidikan formal pada jenjang pendidikan anak usia dini. Dalam Undang-undang Sistem Pendidikan Nasional Nomor 20 Tahun 2003 Pasal 28 menyatakan bahwa "Pendidikan anak usia dini pada jalur pendidikan formal berbentuk Taman Kanak-kanak (TK), Raudhatul Athfal, atau bentuk lain yang sederajat" (Permendikbud Nomor 137 Tahun 2014, 2014). Pada pendidikan taman kanak-kanak yaitu bentuk pendidikan yang berada pada rentang usia 4 tahun sampai 6 tahun. Pendidikan disini ialah pendidikan yang memiliki rentang luas dari keluarga sampai dengan masyarakat.

Metode atau strategi merupakan cara pendidik untuk menyampaikan sumber belajar kepada peserta didik. Faktor yang terpenting dalam penyampaian materi serta sumber pembelajaran yang tepat kepada peserta didik yaitu dalam pemilihan strategi pembelajaran. Dalam melaksankan pembelajaran tidak selalu dilaksankan dengan bertatap muka antara pendidik dan siswa maupun perangkat lainya. Sekarang yang dialami semua kalangan terutama di dunia pendidikan yang dikarenakan adanya pendemi Covid-19, yang tidak memungkinkan untuk dilakukan pembelajaran tatap muka. Dengan adanya pandemi covid19 bukan berarti pembelajaran dan pendidikan tidak mampu tersampaikan. Sama halnya dengan yang diutarakan (Antara, 2017) menyampaikan bahwa, Program pembelajaran anak usia dini sebagaimana di kelola seharusnya memiliki target dekat dengan kehidupan anak terutama pada kegiatan sehari-hari dan tidak hanya sekedar dapat menyelesaikan tugas diatas lembar kertas, buku, dan majalah.

Melihat pentingnya peran yang orang tua lakukan dalam mendidik anak berdasarkan penelitian yang sudah dilakukan membuktikan bahwa orang tua memiliki tanggung jawab yang besar dalam mencapai perkembangan anak dalam pendidikan. Seperti penelitian yang dilakukan (Haerudin et al., 2020) dalam penelitian ini mengungkapkan bahwa dalam kemampuan prestasi anak belajar peran orang tua berpengaruh besar. Anak yang kurang atau tidak bisa menyelesaikan belajar terdapat orang tua yang kurang memiliki perhatian dalam proses pendidikan anak. Anak yang memiliki semangat untuk belajar maka ada orang tua yang mensupport memberi perhatian anaknya yang memperhatikan kegiatan anak belajar dari rumah. selama proses pembelajaran daring maka perlu adanya perhatian dari orang tua sebagai pengganti guru selama kegiatan pembelajaran. Orang tua memiliki tanggung jawab atas pendidikan anak yaitu sebagai pembimbing selama anak belajar daring, sebagai fasilitator dan juga sebagai pemberi motivator. Selama pembelajaran daring orang tua menggantikan guru yaitu mengajar anak dirumah. Sebagai fasilitator dimana orang tua sebagai fasilitator anak dalam menyediakan sarana dan prasarana untuk anak. Sebagai motivator yaitu orang tua bisa memberikan anak dorongan yang bermakna yang membangun semangat anak walaupun pembelajaran dilaksankan secara daring.

Dalam Peraturan Menteri Pendidikan dan Kebudayaan Republik Indonesia Nomor 119 Tahun 2014 Tentang Penyelenggaraan Pendidikan Jarak Jauh Jenjang Pendidikan Dasar dan Menengah yang menyatakan bahwa sumber dari dilaksanakannya pendidikan yaitu 
dengan menerapkan prinsip-prinsip teknologi yang memuat pendidikan. Dalam (Kemendikbud, 2014) bahwa pendidikan yang dilaksanakan secara jarak jauh merupakan pendidikan formal, dimana dengan menerapkan basis lokasi antara lembaga pendidikan dan peserta didik yaitu terpisah sehingga keduanya bisa menggunakan sumber yang bisa menghubungkan mereka untuk melaksankan pendidikan yaitu bisa dari berbagai teknologi. (Anita, 2020) menyebutkan bahwa dalam bahasa inggris kata daring merupakan online. Dengan begitu online secara umum merupakan keadaan bisa terhubung tanpa bertatap muka. Dengan demikian daring dikaitkan dengan teknologi dan pembelajaran, maka dari itu pembelajaran daring yaitu pembelajaran yang menggunakan teknologi dalam melakukan komunikasi seperti menggunakan media Zoom, Google Meet, dll dengan adanya dukungan internet.

Berdasarkan permasalahan yang telah diuraikan maka dalam penelitian ini bertujuan untuk menjelaskan mengenai 1. Bagaimana bentuk-bentuk pembelajaran daring anak usia dini di taman kanak-kanak dengan orang tua ter-PHK. 2. Bagaimana permasalahan dan solusi pembelajaran daring anak usia dini di taman kanak-kanak dengan orang tua ter-PHK.

\section{METODOLOGI}

Penelitian ini merupakan penelitian kualitatif dengan metode yang digunakan yaitu pendekatan studi kasus. Pendekatan ini dipilih karena subjek sangat spesifik dan penelitian dilakukan dengan berbagai pembatasan (P.A Antara, 2015). Penelitian studi kasus (Hidayat, 2019) merupakan suatu penelitian yang dilakukan untuk mengamati, memahami, dan mengumpulkan informasi mengenai status suatu gejala yang ada, yakni keadaan gejala menurut apa adanya pada saat penelitian dilakukan, dengan tujuan untuk memberikan gambaran terhadap suatu objek penelitian. Penelitian ini menganalisis fenomena pembelajaran daring anak usia dini di taman kanak-kanak dengan orang tua ter-PHK selama masa pandemi covid-19. Studi kasus merupakan pendekatan yang tepat karena kondisi informan yang sangat spesifik dengan karaktersitik yang khas dan berada bersama di Desa Manukaya, Gianyar. Lama waktu penelitian yaitu selama lima bulan yaitu pada 1 Februari sampai 29 Juni 2021. Penelitian dilaksanakan di Banjar Malet, Desa Manukaya, Kecamatan Tampaksiring, Kabupaten Gianyar, Provinsi Bali. Subjek dalam penelitian ini adalah 5 orang anak, 2 orang guru, dan 5 orang tua yang mengalami ter-PHK. Teknik pengumpulan data yang digunakan yaitu observasi, wawancara, dan dokumentasi. Perangkat yang dipakai pengumpulan data yaitu kamera, panduan wawancara terstruktur, dan alat perekam suara. Sedangkan teknik analisis data yang digunakan pada penelitian ini sebagaimana yang dikemukakan Miles dan Hubberman (Agusta, 2014) yaitu reduksi data, display data dan langkah terakhir adalah penarikan kesimpulan.

\section{HASIL DAN PEMBAHASAN}

Dihadapkan dengan kesulitan yang dihadapi ketika masa pandemi covid-19 dimana orang tua banyak yang mengalami PHK, disisi lain orang tua memiliki kewajiban terhadap anak dalam pelaksanaan pembelajaran daring. Setiap orang tua memiliki bentuk pelaksanaan, permasalahan yang dihadapi tidak hanya permasalahan dari anak tetapi ada permasalahan dari orang tua akibat ter-PHK, beserta solusi yang dilakukan yang berbeda-beda selama pembelajaran daring. Secara lebih rinci mengenai bentuk-bentuk pembelajaran daring, permasalahan dan solusi pembelajaran daring anak usia dini dengan orang tua ter-PHK akan dipaparkan sebagai berikut :

\section{Bentuk-bentuk Pembelajaran Daring Anak Usia Dini di Taman Kanak-kanak Dengan Orang Tua Ter-PHK.}

Hasil penelitian ditemukan bahwa bentuk-betuk pembelajaran daring bagi anak usia dini di taman kanak-kanak dengan orang tua ter-PHK yaitu : 


\section{Pendampingan}

Selama anak belajar dari rumah bentuk yang diberikan orang tua yaitu sebagai pendamping bagi anak. Sebagaimana dipaparkan oleh salah satu orang tua di bawah ini.

..Iya...selama pandemi anak saya belajar dari rumah. Karena saya ter-PHK maka saya dapat membimbing dan medampingi anak saya selama belajar dirumah...(CW 4 kutipan wawancara dengan ibu WE)

... mendampingi anak selama belajar. Selain mendampingi anak belajar mengerjakan tugas saya juga selalu memantau bagaimana proses perkembangan anak saya. Mengingat selama pembelajaran di rumah orang tua yang menjadi guru dan harus tau bagaimana perkembangan anak di semua aspek perkembangan. Dalam mendampingi anak belajar saya selalu mendampingi namun untuk waktu saya akan menyesuaikan jika saya pagi berhalangan tetapi saya tetap mendampingi di sore atau malam hari... (CW 2 kutipan wawancara dengan bapak KT)

...Orang tua mendampingi anak pada saat anak belajar dari rumah. Mulai dari persiapan hingga anak selesai mengerjakan tugas yang diberikan dari sekolah (CL 4 observasi ibu WE)

Dengan adanya kondisi tersebut peneliti menjadi tertarik untuk mengkaji, apa sebenarnya bentuk pembelajaran daring anak yang memiki orang tua ter-PHK. Berdasarkan kutipan wawancara dan observasi orang tua selalu meluangkan waktu untuk mendampingi ketika anak belajar dari rumah. Orang tua yang ter-PHK memiliki lebih banyak waktu untuk bisa mendampingi anak selama pembelajaran daring. Orang tua bisa setiap hari memantau kegiatan pembelajaran anak yang dilakukan dari rumah. Walaupun tidak selalu di pagi hari mendampingi anak belajar tetapi orang tua bisa mendampingi anak belajar di sore ataupun di malam hari.

\section{Pemberian Motivasi}

Dampak pandemi Covid-19 pada pendidikan yaitu pembelajaran dilaksanakan dari rumah. Dampak dari adanya pembelajaran dari rumah membuat peserta didik mudah merasa bosan dan jenuh karena anak tidak dapat bermain dan bertemu dengan teman-temannya. Maka dari bentuk pembelajaran daring yang dapat orang tua lakukan yaitu dengan pemberi motivasi kepada anak disaat anak merasa bosan. Sebagaimana dipaparkan oleh beberapa orang tua dibawah ini.

...memberi motivasi anak, karena kadang anak saya tidak mau belajar cepat merasa bosan...(CW 1 kutipan wawancara dengan Ibu KAD)

...menghibur anak saya mengajak anak saya bermain bisa juga dengan saat masak saya libatkan anak saya. Saya memberi motivasi dan support bahwa Pendidikan ini penting untuk anak kedepannya.... (CW 2 kutipan wawancara degan Ibu DM)

....Pada saat anak bosan belajar orang tua memberikan motivasi. Memberikan motivasi yang dapat membangun semangat anak untuk belajar. Dengan memberikan reward berupa es krim...(CL 4 obervasi Ibu WE)

Berdasarkan hasil kutipan wawancara dan observasi orang tua sebagai pemberi motivasi yang selalu bisa membangun anak saat belajar agar anak tetap semangat belajar. Disela-sela orang tau mendampingi anak belajar orang tua juga selalu memberikan motivasi yang positif yang nantinya bisa membangun anak sehingga anak bisa selalu menjaga semangatnya belajar walaupun dilakukan dari rumah.

\section{Pengawasan yang Berkelanjutan}

Selama anak belajar dari rumah pengawasan yang diberikan orang tua menunjukkan bahwa orang tua memiliki bentuk pembelajaran daring dalam mengawasi demi tercapainya 
DOI: $10.31004 /$ obsesi.v6i4.1623

perkembangan anak selama pembelajaran daring anak. Sebagaimana dipaparkan oleh orang tua sebagai berikut :

....iya... anak kami belajar daring. Yang kami lakukan tentunya mengawasi anak belajar dan sebagai penyalur informasi dan pembelajaran yang diberikan dari guru lewat WA group...(CW 2 kutipan wawancara dengan Ibu DM)

...Dan mendapingi serta selalu mengawasi anak dalam mengerjakan tugas-tugas dari sekolah Pengawasan yang saya berikan tidak hanya dalam mengerjakan tugas anak, akan tetapi juga pada setiap kegiatan yang anak lakukan.... (CW 2 kutipan wawancara Ibu KAD)

...pengawasan yang diberikan orang tua tidak hanya pada tugas yang diberikan dari sekolah, tetapi pada kegiatan lainya orang tua selalu memberikan pengawasan pada kegiatan lainya seperti mengawasi anak pada saat sembahyang...(CL 2 observasi KAD)

Berdasarkan kutipan wawancara dan observasi dengan orang tua pengawasan yang berkelanjutan selama anak belajar orang tua selalu pengawasi bagaimana proses anak belajar mulai dari mencari informasi, karena disini orang tua menjadi guru pengganti ketika anak belajar dari rumah, serta selalu mengawasi kegiatan anak di kegiatan yang lainnya. Temuan tersebut dapat digambarkan seperti pada bagan gambar 1.

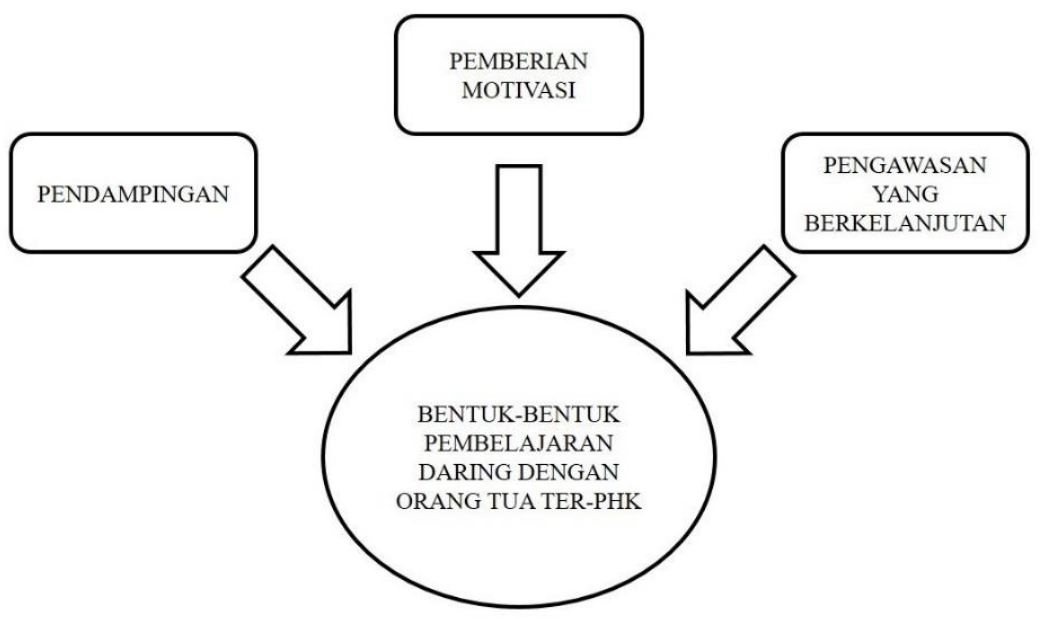

Gambar 1. Bagan temuan penelitian bentuk pendampingan orang tua

Berdasarkan bagan gambar 1 disampaikan pembahasan sebagai berikut:

\section{Pendampingan}

Mengingat untuk tercapainya suatu pendidikan anak usia dini anak usia dini yang bermakna selama pembelajaran jarak jauh (PJJ) sangat perlu adanya dukungan dari sekolah, guru dan orang tua. Ketiga elemen ini sangat membantu dalam proses menciptakan pembelajaran yang dapat menstimulasi semua perkembangan anak. Selama anak belajar dari rumah peran serta tanggung jawab orang tua dalam mendampingi anak untuk menstimulasi semua aspek perkembangan anak sangat diperlukan. (Sudarsana. IK., 2020) menyatakan pendampingan yang dilakukan orang tua pada saat anak belajar dirumah selain mendampingi dalam menyelesaikan tugas orang tua juga selalu memperhatikan perkembangan anak. Selama pembelajaran dari rumah sangat penting peran orang tua dalam menyediakan fasilitas untuk anak belajar menumbuhkan kreativitas anak walaupun anak belajar dari rumah. Sehingga perkembangan anak dapat terstimulasi dengan optimal.

Orang tua bisa setiap hari memantau mengawasi kegiatan pembelajaran dan perkembangan anak yang selama belajar dari rumah. Walaupun orang tua tidak selalu mendampingi anak belajar di waktu pagi hari tetapi orang tua bisa mendampingi anak belajar di sore ataupun di malam hari. (Mawar et al., 2020) meyatakan bahwa pembelajaran daring yang didampingi oleh orang tua mampu membangun semangat belajar anak dan membangun komunikasi yang lebih baik antar orang tua dan anak. Dengan dikeluarkannya peraturan bahwa pembelajaran dilakukan dari rumah tidak hanya menuntut adanya inovasi dari pihak 
sekolah terutama guru namun peran orang tua sangat perlu dimaksimalkan dalam mendampingi dan peran orang tua dalam sebagai pendidik dalam pembelajaraan daring dan pengasuh terhadap perkembangan anak usia dini.

\section{Pemberian Motivasi}

Anak apabila medapatkan dorongan dari orang-orang terdekat anak terutama orang tua maka anak akan memiliki motivasi untuk melakukan ataupun melaksanakan sesuatu. (Mawar et al., 2020) mengungkapkan bahwa setiap anak memiliki bakat masing-masing, jika dalam anak mendapatkan dukungan dan motivasi dari orang tua dan orang terdekat anak maka bakat tersebut dapat berkembang. Dengan begitu adanya motivasi dari orang tua dalam membangun semangat anak belajar maka sangat berpengaruh.

Pada saat mangalami masalah orang tua yang menjadi pelindung untuk anak. Pemberian motivasi ini merupakan salah satu pegasuhan, perlindungan yang diberikan orang tua untuk selalu menjaga anak semangat untuk belajar dari rumah. Dalam memberikan motivasi positif ini komunikasi yang dibangun orang tua sangat penting agar apa yang orang tua sampaikan dapat dengan tepat tersampaikan kepada anak. Selain komunikasi bagimana mengontrol emosi perlu juga diperhatikan dalam proses berpikir untuk disampaikan kepada anak. Selain itu membangun motivasi anak juga bisa dilakukan dengan cara melibatkan anak pada kegiatan-kegiatan yang membuat anak senang dan kembali membangun semangat dan menabah pengetahuan anak. Hal tersebut sejalan dengan yang dikemukan oleh Iftitah \& Anawaty (2020) bahwa kreatifitas anak dapat dibangun dengan adanya komunikasi yang terbuka antara anak dan orang tua. Maka dari itu bentuk pembelajaran daring selama anak belajar dari rumah orang tua memahami situasi bagaimana memberikan respon dan motivasi kepada anak.

\section{Pengawasan Berkelanjutan}

Menyediakan waktu luang untuk mendampingi anak saat melakukan kegiatan belajar merupakan salah satu bentuk pengawasan yang orang tua dapat berikan kepada anak (Wardhani \& Krisnani, 2020). Orang tua yaitu dengan selalu pengawasi bagaimana proses anak belajar mulai dari mencari informasi, karena pada umumnya anak usia dini belum mengerti betul tentang benda elektronik yang digunakan sebagai media pengakses informasi belajarnya serta peran orang tua sebagai guru pengganti ketika anak belajar dari rumah, dan menjadi media penyalur untuk pembelajaran yang diberikan guru melalui WhatsApp grup. Pengawasan orang tua tidak terbatas pada pengerjaan tugas anak. Pengawasan orang tua berkelanjutan pada kegiatan lain yang anak lakukan, itu merupakan bentuk dari pembelajaran daring yang diberikan oleh orang tua. Orang tua mempunyai waktu luang untuk bisa berbincang dan bercerita maka anak akan lebih memiliki sifat untuk bisa terbuka dengan orang tuanya. Maka dari sini, fungsi keluarga yaitu memberikan pengasuhan baik secara fisik, ekonomi maupun psikosional. Orang tua memberikan rasa nyaman dalam mengawasi anak belajar daring.

\section{Permasalahan Pembelajaran Daring anak usia dini dengan orang tua ter-PHK}

Adapun permasalahan yang dialami anak dan orang tua yang ter-PHK selama pembelajaran daring dapat dipaparkan sebagai berikut :

\section{Dana pendidikan}

Selama dilaksankan pembelajaran daring permasalahan yang muncul tidak hanya dari anak, akan tetapi adapun permasalahan yang muncul dari orang tua anak, sebagaimana dipaparkan oleh beberapa orang tua dibawah ini:

... pembelajaran daring online yang menjadi masalah itu di HP dan tidak memiliki kuota internet...(CW1 kutipan wawancara dengan ibu KAD) 
DOI: $10.31004 /$ obsesi.v6i4.1623

...permasalahan mengingat saya ter-PHK terkadang saya tidak memiliki internet untuk mengirim tugas anak saya...(CW 4 kutipan wawancara dengan ibu WE)

...saya juga kendala dalam pembelian paket internet agar selalu aktif di WA... (CW 2 kutipan wawancara dengan ibu DM)

Berdasarkan kutipan wawancara diatas maka permasalahan selama pembelajaran daring dengan orang tua ter-PHK tidak hanya muncul dari anak tetapi ada permasalahan yang muncul dari orang tua. Sebagaimana dipaparkn bahwa masalah orang tua yaitu terkendala dalam pembelian kuota maka orang tua memiliki permasalahan dana bagaimana orang tua terkendala dalam meyediakan fasilitas penyalur anak belajar daring.

\section{Penanganan kebosanan anak}

Pembelajaran daring memberikan pengaruh besar terhadap anak dimana anak terbiasa belajar disekolah bertemu dengan teman banyak, akan tetapi selama pembelajaran daring anak belajar dari rumah tentunya menimbulkan rasa bosan, sebagimana dipaparkan oleh beberapa orang tua dibawah ini :

...Permasalahn terkadang anak merasa bosan dengan pembelajarn yang dilaksanakn dirumah...(CW 2 kutipan wawancara dengan ibu DM)

...selama pembelajaran daring permasalahan yang ada yaitu pertama permasalahan dimana anak terkadang bosan belajar dari rumah karena tidak dapat bertemu dengan teman-teman dan tidak dapat bermain disekolah...(CW 4 kutipan wawancara dengan ibu WE)

... permasalahan seperti anak kadang merasa bosan saat belajar...(CW 2 kutipan wawancara dengan bapak KT)

Berdasarkan kutipan wawancara tersebut maka permasalahan yang muncul dari anak selama pembelajaran daring yaitu anak mudah merasa bosan saat belajar dari rumah.

\section{Kemalasan belajar anak}

Selama belajar daring tidak hanya bosan karena belajar dari rumah akan tetapi muncul rasa maslas dari anak ketika tidak mau megerjakan tugas yang diberikan oleh guru, sebagaimana dipaparkan oleh beberapa orang tua dibawah ini yaitu :

.... pembelajarn yang dilaksanakn dirumah maka anak kadang tidak mau belajar dan megerjakan tugas yang diberikan oleh guru...(CW 2 kutipan wawancara degan ibu DM)

... juga anak tidak mau megerjakan tugas-tugas yang diberikan...(CW 4 kutipan wawancara dengan ibu WE)

Melalui kutipan wawancara dapat dinyatakan bahwa selama belajar dari rumah timbul kemalasan belajar pada anak ketika mengerjakan tugas yang diberikan guru. Anak merasa malas untu mengerjakan tugas yang diberikan. Maka dari hasil penelitian dapat dilihat pada bagan gambar 2. 


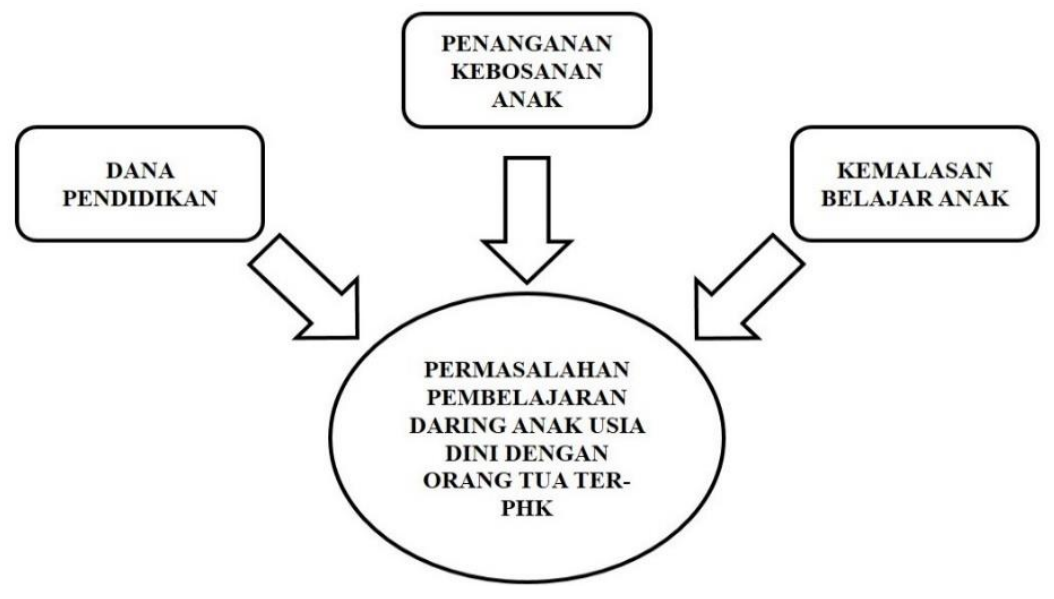

Gambar 2. Bagan temuan penelitian permasalahan pembelajaran daring

Berdasarkan bagan gambar 2 disampaikan pembahasan sebagai berikut:

\section{Dana pendidikan}

Penggunaan teknologi khususnya handphone adalah salah satu alat penting bagi proses pembelajaran daring. Penggunaan handphone tersebut tidak dapat berjalan begitu saja, tetapi harus didukung dengan adanya internet (Adam, 2020). Di masa pandemi covid-19 dana pendidikan menjadi salah satu permasalahan yang dialami oleh orang tua. Dana pendidikan tidak hanya digunakan untuk membeli alat tulis anak saja, tetapi saat pembelajaran daring kuota internet juga harus terpenuhi sebagai alat belajar anak. Salah satu permasalahan yang dialami oleh orang tua yang ter-PHK yaitu pemenuhan kuota internet. Penghasilan yang menurun mengakibatkan orang tua kesulitan untuk membeli kuota internet. Adanya kesulitan ini bisa saja menjadi penghambat untuk anak belajar. Bahkan ada kondisi dimana anak tidak bisa belajar karena tidak ada kuota internet.

\section{Penanganan kebosanan anak}

Kebosanan merupakan hal yang wajar dialami oleh anak. Pelaksanaan pembelajaran daring, dimana anak harus belajar dari rumah masing-masing tidak menutup kemungkinan jika anak akan cepat merasa bosan. Suasana belajar yang monoton, dan anak tidak terbiasa belajar sendiri juga manjadi faktor anak cepat merasa bosan ketika belajar di rumah (Utami, 2020). Orang tua diharapkan dapat menjadi sosok yang mampu menangani permasalahan kebosanan anak selama pembelajaran daring, serta mampu membantu anak jika sudah mulai bosan saat belajar. Kebosanan dalam belajar sangat sering menjadi hambatan ketika anak mengerjakan tugas rumah. Sehingga dalam kondisi seperti ini guru membutuhkan variasi alternatif pembelajaran agar anak tidak dalam kondisi belajar yang monoton.

\section{Kemalasan belajar anak}

Anak usia dini identik dengan belajar sambil bermain, selama pembelajaran daring di masa pandemi covid-19, proses pembelajaran dilakukan dengan cara guru mengirimkan tugas yang harus dikerjakan anak kepada orang tua. Terkadang orang tua tidak memiliki kemampuan untuk membuat suasana yang menyenangkan, serta kurangnya waktu orang tua untuk menemani anak belajar sehingga dapat menyebabkan anak merasa malas untuk belajar dan mengerjakan tugas sekolah (Trisnawati \& Sugito, 2020).

\section{Solusi yang dilakukan orang tua ter-PHK untuk mengatasi permasalahan yang dialami anak saat prores pembelajaran daring}

Adapun solusi yang dilakukan orang tua ter-PHK untuk mengatasi permasalahan yang dialami anak saat prores pembelajaran daring dapat dipaparkan sebagai berikut:

\section{Bimbingan yang terarah}


DOI: $10.31004 /$ obsesi.v6i4.1623

Selama pembelajaran daring ada saja kendala yang dialami oleh anak, salah satunya anak merasa bosan saat belajar. Orang tua memberikan bimbingan yang terarah kepada anak untuk menjelaskan tentang pentingnya untuk melaksanankan pembelajaran, sebagaimana dipaparkan oleh beberapa orang tua dibawah ini:

...solusi yang kami lakukan saat mengalami kendala tersebut memberi bimbingan agar anak mengetahui bahwa pentingnya belajar... (CW 1 kutipan wawancara dengan ibu WP)

...Saya juga memberikan dorongan kepada anak dan semangat bahwa Pendidikan ini penting bagi anak...(CW 2 kutipan wawancara dengan bapak KT)

...orang tua terlihat selalu memberikan bimbingan semangat kepada anak, saat anak sudah mulai merasa bosan belajar (CL 2 observasi ibu DM)

Dari hasil kutipan wawancara dan obsevasi di atas menunjukan bahwa ketika anak mulai malas mengerjakan tugas, solusi yang dilakukan orang tua yaitu memberi bimbingan yang terarah kepada anak. Bimbingan ini dilakukan agar menjadi hal baik di masa depan maka anak harus rajin belajar, serta orang tua juga memberikan penjelasan bahwa pendidikan itu penting bagi masa depan anak yang lebih baik .

\section{Apresiasi}

Pembelajaran daring menjadi cara alternatif yang diterapkan dalam dunia pendidikan. Selama proses pembelajaran daring dilaksanakan di rumah siswa masing-masing. Akibatnya, anak sering malas mengerjakan tugas. Oleh karena itu solusi yang lakukan orang tua untuk mengatasi anak bosan saat pembelajaran daring dipaparkan oleh beberapa orang tua sebagai berikut:

...terkadang saya juga memberikan anak saya reward setelah selesai mengerjakan tugasnya. Seperti saya berikan 1 es krim agar dia merasa juga dihargai... (CW2 kutipan wawancara dengan ibu DM) ...Saya juga memberikan anak sekali-kali reward agar bisa membangun anak dan mau megerjakan tugasnya... (CW 4 kutipan wawancara dengan ibu WE)

...Terlihat orang tua memberikan reward berupa makanan kesukaan anak, saat anak sudah berhasil menyelesaikan tugas sekolahnya (CL 2 observasi ibu DM)

Dari hasil kutipan wawancara dan observasi di atas menunjukkan bahwa orang tua sesekali memberikan apresiasi dengan cara pemberian reward kepada anak. adanya apresiasi dari orang tua dapat memunculkan semangat anak untuk belajar, serta anak juga akan merasa bahwa apapun yang anak lakukan dengan baik akan mendapat support daring orang tua.

\section{Berjualan}

Permasalahan saat pembelajaran daring tidak hanya muncul dari anak, tetapi juga dari orang tua. Orang tua yang mengalami ter-PHK mengalami penurunan penghasilan. Sebagaimana yang dipaparkan beberapa orang tua tentang solusi yang dilakukan untuk mengatasi permasalahan pembelajaran daring anak sebagai berikut:

...Adik saya berjualan online saya melihat dengan berjualan online kosmetik masih ada peluang mencari uang dari sana saya mulai ikut mempromosikan dan berjualan kosmetik online. Maka dari sanalah kebutuhan-kebutuhan keluarga saya bisa terpenuhi. Itu termasuk menunjang anak saya dalam memenuhi kebutuhan dalam pembelajaran daring... (CW1 kutipan wawancara dengan ibu WP)

...Kebetulan saya mempunyai hobi masak dari sanalah saya mencoba untuk berjualan lauk yang sudah jadi, agar bisa memenuhi kebutuhan sehari-hari dan bisa untuk menunjang anak saya melakuakn pembelajaran daring...(CW 2 kutipan wawancara dengan ibu DM)

...orang tua berjualan dengan cara memposting barang jualan di media sosial (CL 1 obsevasi ibu WP) 
Hasil kutipan wawancara dan observasi di atas menunjukkan bahwa, Untuk menyiasati bagaimana cara agar anak dapat melaksankan pembelajaran daring yaitu banyak orang tua yang berjualan dengan memanfaatkan media sosial untuk mendapatkan penghasilan agar orang tua bisa memenuhi kebutuhan sehari-hari dan penunjang selama pembelajaran daring.

\section{Berladang}

Dampak yang timbul dari adanya pandemi menyebabkan banyak orang tua yang mengalami terPHK. Untuk itu orang tua perlu melakukan banyak hal untuk bisa memenuhi kebutuhan sehari-hari. Sebagaimana dipaparkan beberapa orang tua dari hasil wawancara didapatkan solusi yang dilakukan orang tua untuk mengatasi permasalahan dengan pembelajaran daring sebagai berikut:

...selama pandemi tentunya saya dirumah saja, kebetulan orang tua saya mempunyai ladang disana saya mulai belajar berkebun dengan seadanya...(CW 1 kutipan wawancara dengan ibu WP)

...Untuk solusi itu setelah saya di PHK dan saya masih memiliki ladang dan orang tua saya memelihara 1 sapi, disana saya berkebun kecil-kecilan seadanya sambil mencari makan untuk sapi...(CW 2 kutipan wawancara dengan bapak KT)

...orang tua berladang dengan menanam sayur-sayuran dan bunga, lalu hasilnya akan dijual kembali (CL 4 obsevasi ibu WE)

Berladang menjadi cara lainnya yang dilakukan orang tua untuk bisa mendapatkan penghasilan. Hasil tanaman sayur-sayuran yang didapat orang tua dari berladang digunakan orang tua untuk memenuhi keperluan anak selama pembelajaran daring.

Maka dari hasil penelitian di atas dapat dilihat pada bagan gambar 3.

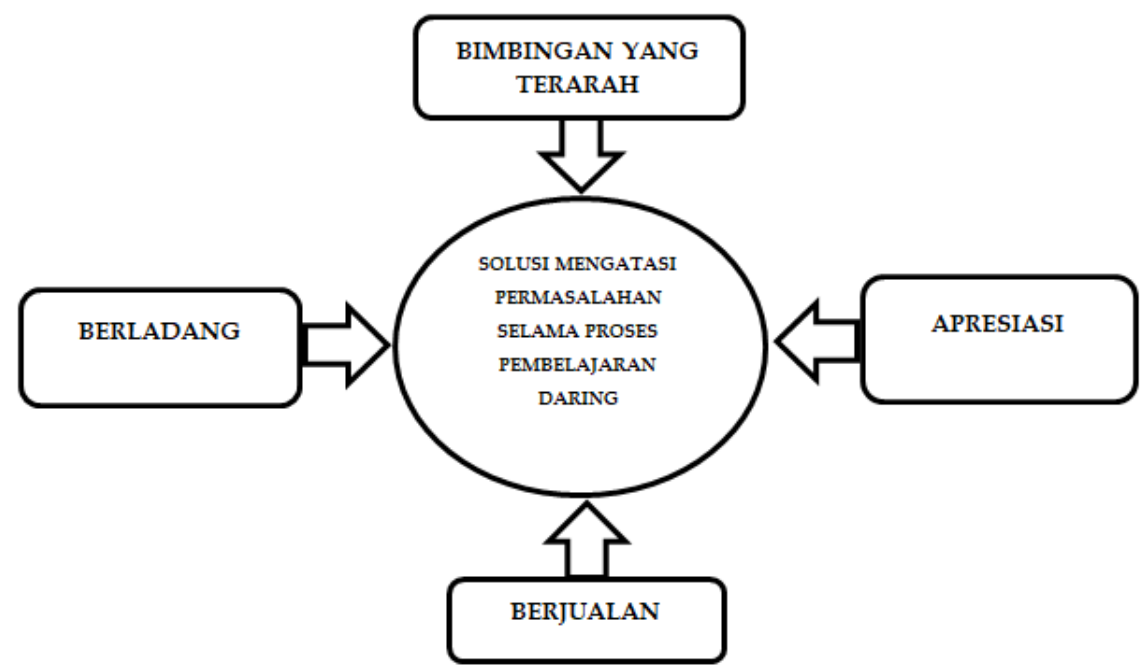

Gambar 3 Temuan penelitian Solusi pembelajaran daring

Berdasarkan bagan gambar 3 dapat disampaikan pembahasan sebagai berikut:

\section{Bimbingan yang terarah}

Ketika anak mulai merasa bosan saat belajar, solusi yang dilakukan orang tua yaitu memberi bimbingan yang terarah kepada anak. (Agusriani \& Fauziddin, 2021) keterbatasan kegiatan belajar yang dilakukan di rumah dapat membuat anak cepat merasa bosan. Untuk itu, bimbingan dari orang tua sangat penting. orang tua memberikan bimbingan yang terarah kepada anak untuk menjelaskan tentang pentingnya untuk melaksanankan pembelajaran dan menuntaskan hasil kegiatan belajar. Bimbingan ini dilakukan agar menjadi hal baik di masa depan maka anak harus rajin belajar, serta orang tua juga memberikan penjelasan bahwa pendidikan itu penting bagi masa depan anak yang lebih baik. 


\section{Apresiasi}

Ketika anak sudah merasa malas dan tidak mau mengerjakan tugasnya, orang tua dapat memberikan apresiasi sebagai dorongan untuk anak berupa pemberian reward agar anak mau mengerjakan tugas-tugasnya. Menurut (Abdillah, 2020)reward bisa dijadikan sebagai strategi untuk membangkitkan semangat anak saat belajar. Dengan memberikan hadiah kepada anak, maka anak akan merasa bahwa apa yang sudah anak lakukan itu dihargai. Pemberian hadiah juga dapat membuat anak semangat untuk menyelesikan tugasnya, serta anak akan merasa apapun yang anak kerjakan anak mendapat dukungan dari kedua orang tuanya di rumah. Dan pembinaan seperti ini terjadi peningkatan perilaku yang benar dan sesuai target yang ditetapkan dalam rancangan pembelajaran yang ditetapkan guru di sekolah. Apresiasi yang dilakukan oleh orang tua biasanya berupa pemberian hadiah seperti makanan yang disukai oleh anak.

\section{Berjualan}

Permasalahan dari diberlakukannya pembelajaran daring tidak hanya muncul dari anak saja, tetapi juga dari orang tua. Mengingat di masa pandemi covid-19 banyak orang tua yang ter-PHK terutama pada usaha pariwisata. Di masa pandemi covid-19 banyak karyawan yang mengalami kehilangan pekerjaannya (Syahrial, 2020). Adanya pandemi covid-19 banyak orang tua mengalami PHK, sehingga orang tua tidak mendapat penghasilan. Tetapi kebutuhan belajar anak harus tetap terpenuhi walaupun berada di masa sulit seperti sekarang ini. Sehingga orang tua harus pintar untuk mencari solusi agar anak masih tetap bisa belajar ditengah kesulitan yang dialami. Salah satu solusi yang dipilih yaitu berjualan dilakukan orang tua untuk dapat memenuhi kebutuhan sehari-hari dan kebutuhan pembelajaran daring anak. Berbagai kegiatan jualan yang dilakukan seperti penjualan kebutuhan pokok dan kebutuhan harian untuk masyarakat sehingga sangat prospektif di masa pandemi ini. Kebutuhan harian seperti lauk pauk dan kosmetik menjadi salah satu komoditi yang bisa dipakai sebagai produk dagang. Kewajiban sebagai orang tua untuk memenuhi seluruh kebutuhan sehari-hari dan kebutuhan belajar anak membuat orang tua harus bisa berfikir dan melakukan sesuatu agar seluruh keperluan yang dibutuhkan dapat terpenuhi. Temuan berupa kegiatan berjualan sebagai solusi masa pandemi merupakan salah satu novelty penelitian ini karena kegiatan ini sangat membantu perekonomian keluarga sehingga sekolah anak masih bisa dilanjutkan.

\section{Berladang}

Beberapa orang tua yang mengalami terPHK, mereka memanfaatkan ladang untuk ditanami sayur-sayuran dan kemudian dijual ke pasar. Berladang menjadi kegiatan yang kini banyak dipilih bagi orang tua yang mengalami PHK. Menurut (Suryadi et al., 2020) waktu luang di masa pandemi dapat dimanfaatkan untuk bercocok tanam, pengoptimalan lahan kosong menjadi solusi orang tua untuk bisa memenuhi segala kebutuhan sehari-hari. Adanya lahan kosong ini dapat dijadikan orang tua sebagai salah satu sumber pencaharian agar tetap mendapat penghasilan. Dari hasil kebun yang diperoleh di ladang tidak hanya dijual ke pasar, tetapi orang tua dapat memanfaatkan sayuran tersebut untuk memenuhi kebutuhan seharihari karena sayuran tersebut juga dapat dikonsumsi oleh seluruh anggota keluarga. Kegiatan berladang ini termasuk salah satu novelty dari penelitian ini karena berladang atau bekerja pada sektor pertanian merupakan salusi prospektif dibalik terganggunya usaha bidang pariwisata akibat pandemi ini.

\section{SIMPULAN}

Bentuk-bentuk pembelajaran daring seperti orang tua melakukan pendampingan yaitu orang tua yang ter-PHK lebih banyak mempunyai waktu untuk mendampingi anak belajar 
daring hal ini sekaligus menjadi hal menarik dalam penelitian ini, selain itu orang tua melakukan pemberian motivasi yang berkualitas yang membangun semangat anak tetap belajar daring karena waktu pendampingan yang lebih banyak dan leluasa, disisi lain orang tua bisa melakukan pengawasan berkelanjutan yang dilakukan tidak hanya pada saat anak belajar tetapi pengawasan pada semua aspek perkembangan. Permasalahan yang muncul tidak hanya permasalahn dari anak akan tetapi ada permasalahan yang muncul dari orang tua, adapun permasalahan yaitu dana pendidikan orang tua dalam menyediakan fasilitas anak belajar daring , penanganan kebosananan anak dan kemalasan belajar anak selama anak belajar dari rumah. Adapun solusi dalam masalah pembelajaran daring pada orang tua ter-PHK yaitu bimbingan yang terarah pada setiap aktifitas pembelajaran daring anak, apresiasi atas berbagai pencapaian pembelajaran, berjualan lauk pauk dan kosmetik serta berladang dengan komoditi sayuran merupakan pilihan yang sangat prospetif.

\section{UCAPAN TERIMA KASIH}

Terima kasih kepada semua pihak yang telah terlibat dalam penyusunan artikel ini. Kepada teman-teman yang terlibat dalam penyusunan dan pencarian data penelitian, serta seluruh pihak lainnya yang terlibat dalam memberikan jawaban atas pertanyaan penelitian

\section{DAFTAR PUSTAKA}

Abdillah, R. H. (2020). Efektifitas BION (Bintang Online) Dalam Meningatkan Motivasi Belajar Siswa Pada Masa Pandemi Covid 19 di Kelas V SDN 1 Ngembel. Jurnal Pendidikan Dasar Nusantara, 6(1), 184-198. https://doi.org/10.29407/jpdn.v6i1.14674

Adam, D. I. T. R. (2021). Dampak Pembelajaran Online Terhadap Efektifitas Mengajar Guru Dimasa Pandemi Covid-19. Journal of the American Chemical Society, 123(10), 2176-2181. http://www.fkipumkendari.ac.id/assets/upload/plp_magang/c40af639d2d95f7f93cd2fc f10e974b8.pdf

Aditya, P. (2015). Pengembangan Bakat Seni Anak Pada Taman Kanak-Kanak Development of Children ' S Artistic Talent. Jurnal Ilmiah Visi PPTK PAUDNI, 10(1), 29-34. https://doi.org/10.21009/JIV.1001.4

Agusriani, A., \& Fauziddin, M. (2021). Strategi Orangtua Mengatasi Kejenuhan Anak Belajar dari Rumah Selama Pandemi Covid-19. Jurnal Obsesi : Jurnal Pendidikan Anak Usia Dini, 5(2), 1729-1740. https://doi.org/10.31004/obsesi.v5i2.961

Agusta, I. (2014). Teknik Pengumpulan dan Analisis Data Kualitatif. Jurnal Studi Komunikasi Dan Media, 02(1998), 1-11.

Anita, S. R. I. (2020). Penerapan Pembelajaran Dalam Jaringan ( Daring ) Pada Anak Usia Dini Selama Pandemi Virus Covid-19 Di Kelompok a Ba Aisyiyah Timbang Kecamatan Kejobong Kabupaten Purbalingga. Iain Purwokerto, 106. http://ojs.diniyah.ac.id/index.php/Al-Mutharahah

Antara, P. A. (2017). Menelisisk Fenomena Kelas Kreatif Pada Taman Kanak-Kanak Di Bali. EJournal Universitas Pendidikan Ganesha ISBN, 602-978.

Antara, P. A. (2019). The Implementation Of Early Childhood Character Education. Jurnal Ilmiah VISI PGTK PAUD Dan Dikmas, 14(1), 17-26. https://doi.org/10.21009/JIV.1401.2

Chapnick, A. (2008). The golden age. International Journal, 64(1), 205-221. https://doi.org/10.1177/002070200906400118

Haerudin, Cahyani, A., Sitihanifah, N., Setiani, R. N., Nurhayati, S., Oktaviani, V., \& Sitorus, Y. I. (2020). Pembelajaran Di Rumah Sebagai Upaya Memutus Covid-19. Universitas Singaperbangsa Karawang, May, 1-12.

Hidayat, T. (2019). Pembahasan Studi Kasus Sebagai Bagian Metodologi Penelitian. ResearchGate, 1-13(August), $1-13$. https://www.researchgate.net/publication/335227300_Pembahasan_Studi_Kasus_Sebag ai_Bagian_Metodologi_Penelitian 
DOI: $10.31004 /$ obsesi.v6i4.1623

Iftitah, S. L., \& Anawaty, M. F. (2020). Peran Orang Tua Dalam Mendampingi Anak Di Rumah Selama Pandemi Covid-19. JCE (Journal of Childhood Education), 4(2), 71. https://doi.org/10.30736/jce.v4i2.256

Kemendikbud. (2014). Peraturan Menteri Pendidikan dan Kebudayaan Republik Indonesia Nomor 119 Tahun 2014 tentang Penyelenggaraan Pendidikan Jarak Jauh Jenjang Pendidikan Dasar dan Menengah (Issue 1650, pp. 1-12).

Kemendikbud. (2020). Jika Satuan Pendidikan Sudah Memenuhi Semua Daftar Periksa Dan Siap Melakukan Pembelajaran Tatap Muka. Panduan Penyelenggaraan Pembelajaran Pada Tahun Ajaran Dan Tahun Akademik Baru Di Masa Pandemi Covid-19. https://www.kemdikbud.go.id/main/files/download/d16ebb4e0e2245e

Khairi, H. (2018). Karakteristik Perkembangan Anak Usia Dini dari 0-6 Tahun. Jurnal Warna, 2(2), 15-28. https://ejournal.iaiig.ac.id/index.php/warna/article/view/87

Mawar, Salamah, D. N., \& Fauziah, A. L. (2020). Sosialisasi peranan orang tua dalam pembelajaran daring bagi anak usia dini di masa pandemi COVID-19. Seminar Nasional Pengabdian Masyarakat LPPM UMJ, 102, 1-10. https://doi.org/10.17509/cd.v12i1.26702

Nasution, D. A. D., Erlina, E., \& Muda, I. (2020). Dampak Pandemi COVID-19 terhadap $\begin{array}{llll}\text { Perekonomian Indonesia. Jurnal } & \text { Benefita, }\end{array}$ https://doi.org/10.22216/jbe.v5i2.5313

Ngadi, N., Meliana, R., \& Purba, Y. A. (2020). Dampak Pandemi Covid-19 Terhadap Phk Dan Pendapatan Pekerja Di Indonesia. Jurnal Kependudukan Indonesia, 2902, 43. https://doi.org/10.14203/jki.v0i0.576

Permendikbud Nomor 137 Tahun 2014, (2014).

Sudarsana. IK., E. a. (2020). Covid-19: Perspektif Pendidikan. In Covid-19: Perspektif Pendidikan (Issue 07).

Supriatna, E. (2020). Wabah Corona Virus Disease (Covid 19) Dalam Pandangan Islam. SALAM: Jurnal Sosial Dan Budaya Syar-I, 7(6). https:// doi.org/10.15408/sjsbs.v7i6.15247

Suryadi, M., Azis, M., \& Hartono, M. D. (2020). Dampak Pandemi Covid-19: Perspektif Adaptasi dan Resiliensi Sosial Ekonomi Pertanian. In Badan Ketahanan Pa.

Syahrial. (2020). Dampak Covid-19 terhadap Tenaga Kerja di Indonesia. Ners, 4(23), 21-29. https://doi.org/10.31004/jn.v4i2.1022

Trisnawati, W., \& Sugito, S. (2020). Pendidikan Anak dalam Keluarga Era Covid-19. Jurnal Obsesi : Jurnal Pendidikan Anak Usia Dini, 5(1), 823-831. https://doi.org/10.31004/obsesi.v5i1.710

Utami, E. (2020). Kendala dan Peran Orangtua dalam Pembelajaran Daring Pada Masa Pandemi Covid-19. Prosiding Seminar Nasional Pascasarjana, 471-479. https:// proceeding.unnes.ac.id/index.php/snpasca/article/download/637/555

Wardhani, T. Z. Y., \& Krisnani, H. (2020). Optimalisasi Peran Pengawasan Orang Tua Dalam Pelaksanaan Sekolah Online Di Masa Pandemi Covid-19. Prosiding Penelitian Dan Pengabdian Kepada Masyarakat, 7(1), 48. https://doi.org/10.24198/jppm.v7i1.28256 